\title{
Spatial Strategies of Urban Development: Rescaling and Territorialization in Post Reform China
}

\author{
J. Shen ${ }^{*}$ \\ Department of Geography and Resource Management, The Chinese University of Hong Kong, Shatin, NT, Hong Kong
}

\begin{abstract}
This paper considers the urban spatial changes in China as rescaling and territorialization processes. Decentralization has led to the emergence of localism in China, in a fashion similar to western cities but with unique features and context of a transitional economy. Acquiring urban status and expanding urban space have become a new strategy for lasting local development, resulting in a massive urban space re-organization in Chinese history. The case of China shows that the rescaling of the state and the city means relative changes in the roles of the central and local states. The central state continues to play an important role while the local states, the urban governments, actively engage in urban spatial changes for the local land, economic and financial interests.
\end{abstract}

Keywords: Scale, state, city, localism, local development, China.

\section{INTRODUCTION}

Dramatic sociospatial transformation has taken place in North American and western European cities and regions, due to the triple processes of denationalization, destatization and internationalization [1-3]. These processes have resulted in the rescaling of regulatory codes, norms and institutions downward or upward [4-6]. The scale theory has been developed to describe the scalar organization of capitalism. The transitional economies are also experiencing various processes of sociospatial transformation. It is argued that the general principle of scale theory also applies to socialist transitional economies, where scalar configuration has been rearticulated by liberalization and globalization involving twin issues of governance and scale [7-9].

There is a hierarchical administrative system in China. The country is divided into local administrative units at provincial level, prefecture level, county level and town/township/sub-district level. Provinces administrate various cities and counties. Prefectures are the agents of provincial government. Counties and townships are rural administrative units. Cities, urban districts, sub-districts and towns are urban administrative units. Cities can be designated at provincial level, prefecture level and county level, depending on their administrative status. A provincial or prefecture level city may administrate urban districts, county-level cities and counties, but with limited control over county-level cities and counties. An urban district or county-level city may administrate sub-districts, towns and townships. Thus local administrative units in China include provinces, prefectures, cities, counties/urban districts and towns/townships/ sub-districts (Fig. 1). Generally, only urban districts in various cities and towns/sub-districts in various county-level cities and counties are considered as urbanized areas in

*Address correspondence to this author at the Department of Geography and Resource Management, The Chinese University of Hong Kong, Shatin, NT, Hong Kong; E-mail: jianfa@cuhk.edu.hk
China. Cities in China are a kind of important local administrative units. An urban government is an important local state. Many studies have been conducted on the urban transformation in transitional China [10-14]. The urban changes in China are influenced by the changing relations between the central and local states that have been the focus of some studies [15-17].

Urban governance approach has been adopted in the previous studies. Zhu cautiously used concepts of urban regime and urban growth machine in an analysis of the urban dynamics in China [18]. He found that an informal local growth coalition is formed between local state and enterprises. Zhang formally adopted the urban regime theory in the study of Shanghai [19]. He concluded that the concepts of urban governance work well with the economic dimension, but differ from the political dimension of urban governance due to a strong government and tight social control in China.

However, urban growth machine and urban regime theories are internalistic paradigms of urban politics disregarding the scalar issue [4]. A scalar analysis would consider the global forces, the central state and the local actors in a city [20]. The production and construction of geographical scale involve the processes of scaling and rescaling. First, scaling refers to "the establishment of geographical differences according to a metric of scales - etches a certain order of empowerment and containment into the geographical landscape" [21]. Second, rescaling refers to the shifting in the power and control over scales. Territorialization and deterritorialization are involved simultaneously in such a rescaling process. According to Storper, "an activity is fully territorialized when its economic viability is rooted in assets (including practices and relations) that are not available in many other places and that cannot easily or rapidly be created or imitated in places that lack them" [6]. Deterritorialization takes place when an economic activity is not attached to a specific place. One important form of de- or re-territorialization is the shrinking or expansion of physical space. 


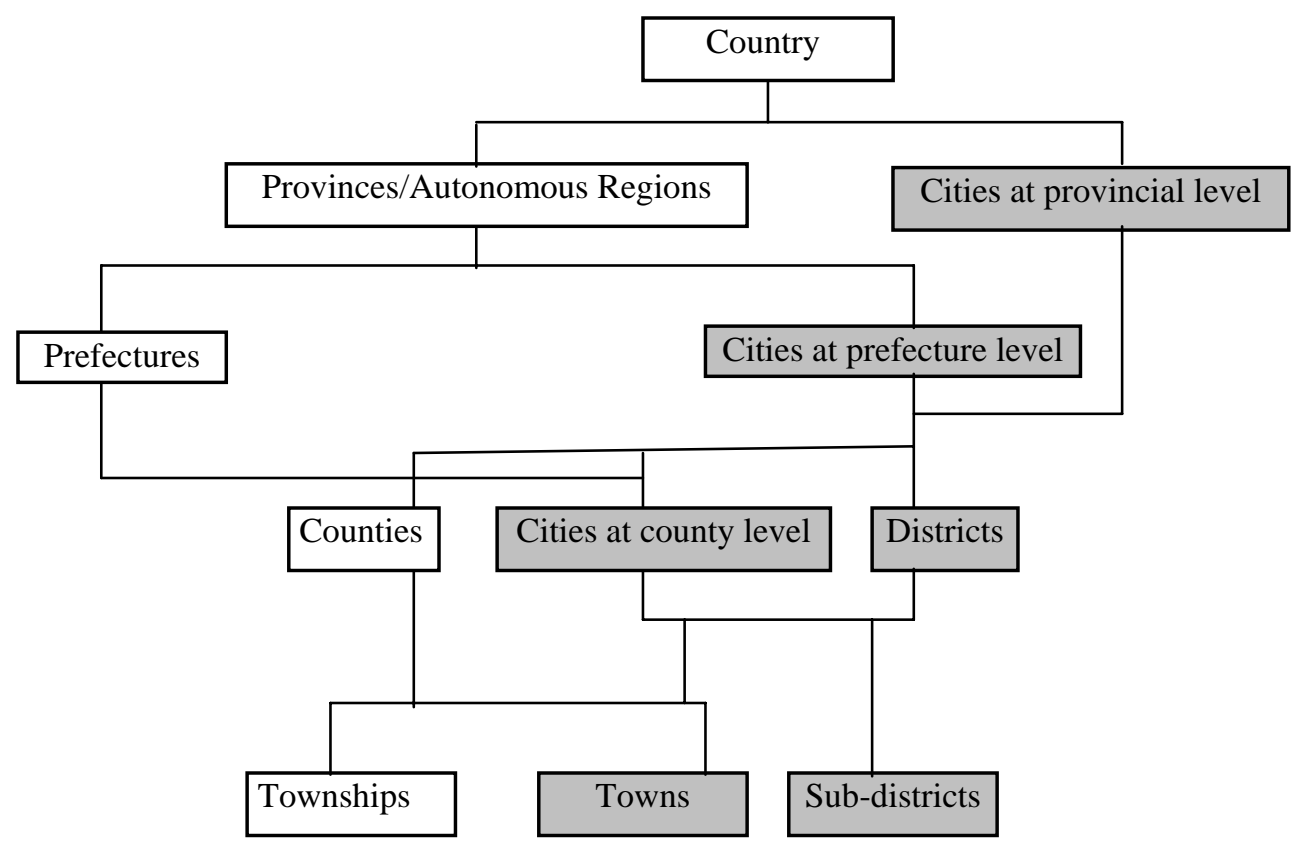

\section{Urban administrative units:}

Fig. (1). Cities under hierarchical administrative system in China.

Since 1978, the urban space in China has been expanded/re-organized tremendously with the designation of new cities and the constant adjustment of city boundaries. The role and function of the state have been contested and reconfigured consequently at various spatial levels. This paper adopts the scale theory to describe the profound transformations of the state and the city in China.

\section{THE EMERGENCE OF CITIES AS AUTONOMOUS LOCAL STATES}

There is a hierarchical administrative system in China from the top of central government down to provincial, city, county and town/township governments. Before 1978, the system was highly centralized. The central government administrated the economy and the society through its areabased administrative system and its sector based administrative system. Various ministries were part of the central government. They were located in the capital although their offices and controls have reached many local areas in the country. The centralized system before 1978 relied on the sector control for central planning at the expense of area-based units. Local governments had little autonomy and they actually became passive actors following ministerial orders in their daily activities. For example, the former Ministry of Light Industry had greater influence on a state-owned textile mill in Shanghai than the municipal government of Shanghai.
Since the early 1980s, urban governments have assumed an increasing role in local development in China due to economic and institutional reforms. There has been a clear tendency of decentralization and liberalization initiated and settled through the intense interaction of central and local governments, SOEs (state owned enterprises), non-SOE enterprises and residents. The four scales of concern are the national scale, the local scale (especially cities), enterprises and residents. This paper will focus on the rescaling of the state and the city at national and urban scales.

As an integral part of China's economic reforms, the decentralization and marketization processes are perhaps the most influential in the rescaling of political economy and governance in China. The central planning system has been gradually replaced by the market mechanisms in China. By 1998, most of the industrial and agricultural production was based on market. The share of industrial production based on the state plan in the total value of industrial output was reduced from $70 \%$ in 1979 to $4.6 \%$ in 1998 . The share of goods with prices under state regulation in the total value of traded goods reduced from over $95 \%$ in 1979 to only $7.2 \%$ in 1998 [22]. The central state has also been reconfigured to cope with the emerging market economy. For example, through four major reforms in the organization of the central government in 1982, 1988, 1993 and 1998, the number of ministries and commissions under the state council was reduced from 100 before 1982 to 53 in 1998 [22]. 
With further integration of China with the world, globalization has increasing impact on internal institutional reforms. For example, to make its economic regulation consistent with WTO (World Trade Organization) rules after China's entry into WTO in 2001, many government regulations and administrative rules inconsistent with WTO need to be abolished. It is estimated that the central government has about 20,000 kinds of administrative power to approve various projects and applications, while the provincial government has over 10,000 kinds of power. After the entry of WTO, the central government has abolished 830 regulations and 250 revised regulations, out of 2300 regulations involving foreign investment and trade [23].

During the rescaling process, local governments, firms and residents acquire great power and flexibility in their management, operation and competition with others. The local states have gained great autonomy in fiscal operation, financing, investment and enterprise administration [19].

Most local governments adopt an aggressive pro-growth development strategy. Stimulating economic growth and expanding the revenue base have become two key goals of local states. According to a survey of 56 officials in 11 cities in Jiangsu in 2000, 70\% chose increasing economic growth rate as the top investment motivation of local governments (Table 1). They are keen to invest in and serve the firms that are the source of revenue [24]. In 1999, the fiscal expenditure of local government on firms was RMB60 billion. Comparing with cities in western countries, local governments spend little in providing public facilities like education and medical services to residents especially in newly developed residential areas. In 1999, the expenditure on urban maintenance and construction was only RMB47 billion for China as a whole [24]. In the above survey in Jiangsu, only $17 \%$ and $15 \%$ of officials considered improving social security and increasing the employment opportunities as the focus of local governments respectively.

Table 1. The Investment Motivation of Local Governments

\begin{tabular}{|l|c|}
\hline \multicolumn{1}{|c|}{ Motivation } & $\%$ \\
\hline \hline Increase economic growth rate & 70 \\
\hline Increase local fiscal revenue & 45 \\
\hline Improve investment environment & 43 \\
\hline Increase employment & 28 \\
\hline Create living environment & 24 \\
\hline Realize government goals & 17 \\
\hline Source: See [24]. Based on a survey of 56 officials in 11 cities in Jiangsu in Aug. 2000.
\end{tabular}

The rising local states have important implications to urban developments. Among various kinds of administrative units in China, cities are the most important local areas with substantial political, economic and financial power. Provincial governments have decision-making power on some important matters but much power has been decentralized to urban governments. Prefectures are the agents of provincial governments. There are only a few prefectures left, as most prefectures have been converted to cities in the reform period. Thus, the cities have become the most active local areas in the reform period. They have the strongest localism among various localities.

A number of spatial and non-spatial strategies are adopted by local states especially cities to capture financial gains within their boundary. First, the local states are keen to improve their infrastructure such as highways, power supply and communication facilities for local development [25]. Second, the local states are keen to attract foreign investment by offering tax concessions and other policy incentives such as cheap and even free land [18].

Third, they have developed close relations with local firms by direct or indirect participation and intervention. An informal local growth coalition is formed between local state and enterprises. Under "soft budget constraints", SOEs often get financial subsidies and even subsidized land supply to keep them surviving. It remains unclear whether decentralization and the hardening of "soft budget" can regulate the local governments' behavior effectively $[10,26]$. As symptoms of rising localism, many local governments engage in destructive competition in the same or similar industries. In 1998, China produced $1 / 3$ of the world's cement by 8835 firms. But some 75 percent of firms were small in scale, each only producing less than 60,000 tones of low-quality cement [27].

Finally, the above three strategies, if successful, will generate significant land revenue for local states as there is a huge rent gap when agricultural land is turned into industrial and urban land, such as commercial buildings, offices and housing. This is similar to the case in the inner city of western countries, where the rent gap can be created by "continued urban development and expansion" [28].

According to the revised Law of Land Administration of China that has been in force since 1 January 1999 [29], all the land is owned either by the state or rural collectives. The land owned by rural collectives can be converted to state owned land. Rural collectives will be compensated based on the original land use, 6-10 times of the average output for arable land. Resettlement aid, 6-10 times of the average output for arable land, will also be provided. The land revenue from the transfer of land-use rights using such new state owned land would be shared by the central state $(30 \%)$, and the local state $(70 \%)$. Obviously, the compensation for rural collectives and the cost of land development are much smaller than the land revenue acquired by the local state. Thus, a local state is keen in urban land development and in establishing various "development zones" to attract investment causing cutthroat competition in land supply [30]. Thus, the local state has every incentive to expand its area and to convert much arable land for industrial and urban development.

In the period 1987-1996, total urban built-up area was increased from $10817 \mathrm{~km}^{2}$ to $20660 \mathrm{~km}^{2}$ in China [31]. According to the statistics of Ministry of Land and Resources, land for urban construction was increased by 664,800 ha, 368,300 ha which was converted from arable land. The accumulated revenue of land sale reached RMB241.8 billion involving 0.2 million ha in the period 1987-1994. In 2001 alone, 1435 cities and counties in 30 provincial regions, engaged in land sale through tender and auction, generate a total revenue of RMB49.2 billion [32]. Large amounts of 
public and private capital has poured into housing market aiming for lucrative profit, causing a noticeable capital switch from industrial development to land development [33, 34]. High profit rate is a key cause for excessive housing investment. The profit rate of housing developers was as high as $45-50 \%$ in Shenzhen and Beijing, according to a businessman in the real estate sector [35].

In summary, decentralization has led to the emergence of localism. Every local state is interested in attracting and concentrating the development in its own land, which is a kind of urban territorialization. Acquiring urban status and expanding the area under the jurisdiction of local states have become a new strategy for lasting local development, resulting in dramatic urban spatial change in the post reform China.

\section{EXPANDING URBAN TERRITORY: SPATIAL STRATEGIES OF URBAN DEVELOPMENT}

City is an important kind of political unit in China. According to the "Law on the Organization of Local Governments" that stipulated the political power structure of a city in China [36], the People's Congress of a city is the organization with the state power. The city government is not only the executive arm of the People's Congress of a city but also the local administrative arm of the state. Thus, the city government was responsible to both the People's Congress of the city, and the state administrative organization at higher level. Indeed, a government department such as the Department of Civil Affairs in a city government is not only responsible to the city government, but also to the Ministry of Civil Affairs under the central government. This means that the central government has the ultimate power in initiating changes and controlling local governments at various levels. Nevertheless, the relative degree of control and autonomy between the central state and urban governments can change dramatically. As discussed in the previous section, the rising of the local state is the most important event in the reform era.

Urban spatial change in China has two major forms, Rescaling the city, and the urban territorialization. Rescaling the city refers to the case that a city is promoted in the administrative hierarchy from a county level to a prefecturelevel, pro-provincial level or provincial level. Urban territorialization refers to the case that a city's territory expands to include more areas under its control. Through territorial expansion, a city gains control over the land and economic interest in the new area. Table 2 presents a typology of urban spatial changes. These spatial changes include extending urban control to rural areas through the introduction of "citygoverning county system", the conversion of a rural area to an urban area by designating a county as a city, changes in urban status by upgrading to acquire more administrative power, inter-city changes such as converting a city as an urban district of another city, and the merging of cities. In some cases, vertical rescaling and horizontal territorialization can take place simultaneously. For example, a county-level city may be upgraded as a prefecture-level city when the "city-governing county system" is introduced. A "citygoverning city system" emerges when a county-level city is administrated by a prefecture-level city. This section will examine these processes and the interaction among various scales.

Table 2. Typology of Urban Spatial Changes

\begin{tabular}{|c|c|c|}
\hline Category & Vertical Rescaling & $\begin{array}{c}\text { Horizontal Territoriali- } \\
\text { zation }\end{array}$ \\
\hline $\begin{array}{l}\text { Governing } \\
\text { rural area }\end{array}$ & & $\begin{array}{l}\text { City-governing county } \\
\text { system }\end{array}$ \\
\hline $\begin{array}{l}\text { Rural to urban } \\
\text { transition }\end{array}$ & $\begin{array}{c}\text { A county is designated as } \\
\text { a city }\end{array}$ & $\begin{array}{l}\text { A city acquires a county } \\
\text { as its urban district }\end{array}$ \\
\hline $\begin{array}{l}\text { Changes in } \\
\text { city status }\end{array}$ & $\begin{array}{l}\text { Changes from county- } \\
\text { level city to prefecture- } \\
\text { level, pro-provincial level } \\
\text { or provincial level city }\end{array}$ & \\
\hline $\begin{array}{l}\text { Inter-city } \\
\text { changes }\end{array}$ & & $\begin{array}{l}\text { City-governing city sys- } \\
\text { tem; A city acquires a } \\
\text { city as its urban district; } \\
\text { merges of two cities }\end{array}$ \\
\hline
\end{tabular}

\section{Becoming a City}

One important form of urban spatial change is the designation of new cities. Becoming a city is an important urbanization strategy for local development. Local governments especially counties are keen to negotiate with the central state for urban status as the city has several advantages over a county.

First, a county-level city government has greater administrative power than a county government. When a county is designated as a city, it will acquire greater autonomy. For example, a city government can approve a construction project up to US\$30 million, while a county government can only approve a project up to US\$1 million [37]. This is also reflected by a larger and more sophisticated government organization. According to the Central Staffing Committee [36], a city government may set up 30-60 commissions/bureaus, while a county government may only set up 20-30 bureaus.

Second, in terms of planning, a city will be listed separately in the provincial plan, whereas a county will only be listed in a prefecture or prefecture-level city's economic plan [38]. Thus, a city can be considered as an independent unit in the provincial planning and can enter the competition for various construction projects.

Third, financially, a county-level city can use $7 \%$ of the local fiscal revenue for urban maintenance and construction, whereas a county can only use $5 \%$ [31]. This shows that a city government controls more financial resources for urban construction.

Fourth, a city is often considered more superior than a county in the conventional urban-rural dichotomy. A city is much attractive to investors and talents. Manufactured products of a city, the "urban products", are considered better than the products of a county, the "rural products". Giving the overwhelming importance of industrialization and attracting foreign and external investment, acquiring city status is considered very important for local development. The number of county-level cities increased from 130 in 1982 to 400 in 2000 
The rush to convert a county to a city has changed the ways to designate a city. Before 1978, "separating a city from a rural county" was the main form of city designation. An original county was divided into two administrative units, where a county kept most area of the original county and a city kept a small area of the central town. The new city was fully surrounded by the new county. Urban and rural areas were completely separated into city and county. This had a significant impact on the development of the new county. Its urbanization was curtailed, and there was much conflict between the city and the county.

Thus the form of "re-designation a whole county as a city" is adopted in the reform period [39]. A whole county is re-designated as a city if it meets the criteria for city designation. Over $70 \%$ of the current cities in China are designated in this form. Such a city is different from the conventional concept of a city with a central built-up area. A county-level city often consists of several towns and townships. For example, Conghua county was designated as a county-level city in 1994 [40]. It had an area of $2009 \mathrm{~km}^{2}$ and a population of 0.47 million in 1998. It consists of 15 towns and 1865 rural settlements spread over its territory. Its largest town, Jiekou, only had 0.1 million population in an area of $49 \mathrm{~km}^{2}$. In the remaining 14 towns, each only had a non-agricultural population of less than 5000. This is also the reason why one cannot simply count population in a city as urban population in China.

Nevertheless, becoming a county-level city does mean more administrative power and autonomy for the local area. Its central town may experience rapid expansion although the city as a whole looks more like a county in the conventional sense.

\section{Raising City Status}

Raising city status has the effect of acquiring more administrative power similar to the conversion of county as a city. In the reform period, many county-level cities have been upgraded to prefecture-level cities with the introduction of "city-governing county system", which will be discussed in the next sub-section. Other two significant events are the designation of pro-provincial cities and a new municipality.

A new type of pro-provincial city was introduced in 1994, recognizing the increasing role of some large cities in the economy. The key consideration is to facilitate the autonomy of such larger cities for economic development. The status of a pro-provincial city is higher than a prefecture-level city, but lower than a municipality that is under the direct administration of the central government [41]. They are not designated as municipalities as this means a complete separation of these cities from provinces they belong to. Such a move is more controversial and needs much more political deliberation. Thus, the introduction of the proprovincial city status is also a result of political consideration, a convenient vehicle of controlled decentralization.

The pro-provincial cities are given a privileged position in the national plan that their economic plans would be listed separately from their provinces. These pro-provincial cities are still under the administration of provincial governments, but they have the same power as a provincial government in economic planning and administration. In 1997, there were 15 such cities including Shenzhen, Dalian, Qingdao, Ningbo,
Xiamen and the provincial capitals of 10 provinces with strong economic and political status. The list has changed over time as various cities have to persuade the central government for such status, while the central government has the final say in this matter. It is expected that some of these cities may be eventually designated as municipalities, when their economic power is further strengthened, such a change is politically acceptable.

Indeed, a new provincial level municipality, Chongqing, was established in 1997. The old prefecture-level city of Chongqing in Sichuan province was scaled up to the provincial level and expanded to include two prefecture-level cities and one prefecture. In this case, both vertical rescaling and horizontal territorialization took place. The new municipality was established to cope with the migration and development related to the construction of the "Three Gorges Project" which will be constructed during the period 1994-2009. The rescaling of the city has important impact on the development path of Chongqing, and it now acts as a leading central city in the southwestern region of China [42].

\section{Expanding Urban Boundary}

Horizontally, urban territorialization takes place when a city's territory expands and keep more areas under its control. It takes place when a city annexes a county or a countylevel city as its urban district and when two or more cities are merged. When a city's territory is expanded, it will acquire much land for industrial, commercial and housing expansion, be able to gain substantial land revenue, and tax income. As discussed in the previous section, urban expansion is an important territorialization strategy to strengthen a city's political and economic power. It is also an effective measure to curb rising localism in subordinated areas previously out of its jurisdiction.

The adjustment of urban boundaries has major political consequences. When a county or a county-level city is designated as an urban district, it is totally absorbed by the prefecture-level city. Generally, a county or county-level city is an independent political unit with much political and economic power. An urban district is a part of a city and is not an independent political unit. Many political and economic matters are administrated by the city government directly, while the government of urban district is at the lowest government level in a city and often only has the function to provide public services to its residents [37]. Thus, a countylevel city especially its leaders, often opposes changing its status to an urban district.

For example, Huadu and Panyu were two county-level cities under the administration of Guangzhou city before 2000. These two cities had much economic power of their own. On the other hand, industrial and urban development in Guangzhou's urban districts was constrained by limited land. To solve the problem and to gain control of the new international airport, being constructed in Huadu city and the port resources in Panyu city, Guangzhou city annexed Huadu and Panyu as two new urban districts with the approval of the State Council in May 2000. There was a stiff resistance from Panyu that they even appealed to overseas Chinese to preserve its city status [37]. However, the higher-level government in Guangzhou had the final decision power in this matter and the status of Panyu was changed eventually. This 
case shows that a city with higher status like Guangzhou has the advantage and convenience to expand urban space. Their expansion is motivated by the need of controlling land and strategic interests such as port and airport. The city is acting for its own interest like an autonomous entity.

The case of Foshan city and Nanhai city in Guangdong province is another example. Nanhai was designated as a county-level city in 1992, and was under the jurisdiction of the prefecture-level city, Foshan. By 2000, Nanhai was even stronger than Foshan's urban proper in economic terms. Nanhai's GDP was RMB 33.9 billion, while the GDP of the later was RMB 15.9 billion in 2000. The GDP per capita of two cities were RMB 31076 and RMB 33434 respectively [43]. With a strong economy, Nanhai was determined to build a new town center just outside Foshan's urban proper. It was difficult to coordinate the urban infrastructure that fell under the jurisdiction of two competing city governments. The solution taken by the provincial government was to convert Nanhai and other county units as urban districts of Foshan city in 2003. Through such administrative adjustment, the power of the central city, Foshan, was increased. According to an interview with the urban planners in Foshan city conducted at 16 July 2003, the urban planning power of county-level units, such as Nanhai was transferred to the city of Foshan, while other economic administrative powers were still kept with the district governments. This is an example of the way through which new relations have been articulated through compromising between two levels of urban governments.

\section{Merging Cities}

"The merging of two cities" usually involves one prefecture-level city and one county-level city both with strong economic power. This is different from the case that a city or a county is annexed by a dominant city. The merging of two cities means the establishment of a new city government. It is a measure to solve the conflicts of urban developments in two cities.

Before the merger, it was typical that the county-level city attempted to develop its own urban center to gain control on its own urban development, although it is close to the city center of the prefecture-level city. This would result in the duplication of urban facilities. In Jiangsu province, steps have been taken to merge cities to solve with such problems. In 2001, county-level city Wuxian, was merged with prefecture-level city Suzhou, and county-level city Xishan was merged with prefecture-level city Wuxi.

\section{The City Governing County System}

The "city governing county system" is an important way of expanding the area under the jurisdiction of a city. A prefecture would be replaced by such a system so that a prefecture-level city administrates other counties or county-level cities in the former prefecture. A county-level city is often promoted to become a prefecture-level city in such cases. As a result, both vertical rescaling and horizontal territorialization take place simultaneously. The city is scaled up from county-level to prefecture-level, while the urban space under its administration is also expanded.

The objective of "city governing county system" is to strengthen the leading role of a city in a regional economy and the integration of urban and rural economies. In 1982, the system was first implemented in Jiangsu and Liaoning, both were two more developed coastal provinces. The system then was implemented nationwide. By 1994, the system was implemented in all provincial units except Hainan province in China. A total of 741 counties, 31 autonomous counties, 9 banners and 2 special districts were put under the administration of 192 cities. Some 240 county-level cities were also administrated by prefecture-level cities on behalf of provincial governments. Due to the adoption of the "city governing county system" after 1982, many county-level cities were upgraded to prefecture-level cities. The number of prefecture-level cities increased from 112 in 1982 to 244 in 2000. It was noted that some prefecture-level cities, such as Zhongshan and Dongguan in the Pearl River Delta did not administrate any counties or county-level cities.

As mentioned before, the "system of city governing county" is designed to enhance the integration of a central city and its surrounding hinterland, reversing the previous situation of urban-rural separation, but its real consequences are controversial. In some cases, there are intense conflicts in the administrative power and economic interests between the governments of the central city and the county-level units [37]. When a county is under the administration of a province, it has much autonomous power, but when it is governed by a prefecture-level city, the city tightens its administration on the county.

Due to limited resources, the government and the mayor of a central city often focus on the urban proper, while the interests of the county-level units are compromised [37]. A central city may give priority to its urban proper in bidding for large construction projects, foreign investment, and the right for direct foreign trade. Thus a "city governing county system" is regarded as a system of "city exploiting county" and a "city suppressing county", instead of "city helping county" [44, 45]. The mayors of about 20 county-level cities shared this view in a survey [24].

\section{CONCLUSION}

The scale theory is developed mainly in the context of global capitalism to describe the scalar organization of capitalism, paying little attention to the transformation in socialist countries such as China. As a general sociospatial theory, the paper argues that the principle of scale theory is also relevant to transitional socialist economies, where scalar configuration has also been rearticulated by liberalization and globalization. This paper examines the scaling of central and local states that have important implications for urban development. It considers the urban spatial changes as rescaling and territorialization processes.

The rescaling of central and local states is a politically constructed process. It does not simply mean the declining of central state and the rise of local state. There have been intensive interaction and negotiation between local and central governments over administrative power, incentive policies, revenue sharing, taxation, investment projects and loans.

In many cases, the central-local relations have been redefined by the advocating of some advantaged localities. They have lobbied the central state aggressively for special policies so that they can attract foreign investment with preferential measures. As a result, open door policies have been 
extended to a number of areas since 1978 [46]. On the other hand, the local states have every incentive to resist pressure for tax and revenue transfer to the central state.

The central government has also introduced recentralization policies from time to time to gain control over financial resources and administrative power. Regulatory intervention and frequent reshuffles of key local officials are key measures of the central state to curb rising localism. On the other hand, the central government itself also plays an important, sometimes leading role in facilitating the functioning of the local state. For example, the local state has been encouraged to develop the local economy by taking certain measures, following the slogan of "letting some places to get rich first." This is similar to the case of western countries, in terms of scale theory, that "state institutions have arguably played a particularly significant - but hardly exclusive - role in demarcating, reproducing, modifying, destroying and creating anew the major scalar hierarchies and partitions in which everyday life within capitalist society has been configured" [47].

Overall in China, decentralization has led to the emergence of localism with increasing competition instead of cooperation among localities, in a fashion similar to western cities but with unique features and context of a transitional economy [48, 49]. Every local state is interested in attracting and concentrating the development in its own land, a kind of urban territorialization. To meet the increasing needs of industrial and land development, acquiring urban status and expanding the urban area under the jurisdiction of local states have become a new strategy for lasting local development, resulting in a massive urban space re-organization in Chinese history.

Under a hierarchical administrative system, the central government also has substantial power in urban spatial changes. Its influences build on three major vehicles. First, the National People's Congress or the State Council is empowered by the nation's constitution to approve city designation and its boundary changes. Second, the power of central government has been implemented through the hierarchical administrative system. Thus local governments are not completely autonomous. However, the local governments also participate in the process of urban spatial changes actively. Urban spatial changes are often initiated by the local governments concerned. For example, if a city likes to annex other counties or county-level cities as its urban district, then it will be applied to the provincial government, and the State Council as well.

The case of urban spatial changes in China shows that the rescaling of the state has caused profound urban spatial changes, i.e., the rescaling and territorialization of the city. There are relative changes in the influences of the central and local states. The central state continues to play an important role while the local states, the urban governments, actively engage in urban spatial changes for local land, economic and financial interests. Thus the (central) state territoriality does not disappear completely although the states and cities are being dramatically re-scaled and reterritorialized in transitional China [3]. But the driving forces in such sociospatial transformations seem to be different between China and the western countries. The decentralization process initiated internally and dominates these transformations in China, while the impact of globalization process, which dominates the transformation in the western countries, does no emerge in China until recently [50].

\section{ACKNOWLEDGEMENTS}

The work described in this paper was partly supported by a Public Policy Research Grant from Research Grants Council of Hong Kong Special Administrative Region (RGC Project No. CUHK4005-PPR-4).

\section{REFERENCES}

[1] Ohmae K. The end of the nation state: The rise of regional economies. London: HarperCollins 1995.

[2] Lauria M. Introduction: Reconstructing urban regime theory. In: Lauria M, Ed. Reconstructing urban regime theory: Regulating urban politics in a global economy. London: Sage Publications 1997; pp. 1-9.

[3] Brenner N. Globalisation as reterritorialisation: The re-scaling of urban governance in the European Union. Urb Stud 1999; 36(3): 431-51.

[4] Macleod G, Goodwin M. Space, scale and state strategy: Rethinking urban and regional governance. Prog Hum Geog 1999; 23(4): 503-27.

[5] Swyngedouw E. Neither global nor local: "Glocalization" and the politics of scale. In: Cox KR, Ed. Spaces of globalisation. New York: The Guilford Press 1997; pp. 137-66.

[6] Storper M. Territories, flows and hierarchies in the global economy. In: Cox KR, Ed. Spaces of globalisation. New York: The Guilford Press 1997; pp. 19-44.

[7] Nee V. Organizational dynamics of market transition: Hybrid form, property rights, and mixed economy in China. Adm Sci Q 1992; 37(1): 1-27.

[8] Yeh AG, Wu F. The new land development process and urban development in Chinese cities. Inter J Urb Reg Res 1996; 20(2): 330-54.

[9] Wei YD. Decentralization, marketization and globalisation: The triple processes underlying regional development in China. Asian Geog 2001; 20(1/2): 7-23.

[10] Wu F. Urban restructuring in China's emerging market economy: Towards a framework for analysis. Inter J Urb Reg Res 1997; 21(4): 640-63.

[11] Fan CC. The vertical and horizontal expansions of China's city system. Urb Geog 1999; 20(6): 493-515.

[12] Shen J. Chinese urbanization and urban policy. In: Lau CM, Shen J, Eds. China review 2000. Hong Kong: The Chinese University Press 2000; pp. 455-80.

[13] Ma LJC. Urban transformation in China, 1949-2000: A review and research agenda. Environ Plan A 2002; 34(9): 1545-69.

[14] Pannell C. China's continuing urban transition. Environ Plan A 2002; 34(9): 1571-89.

[15] Wong CPW, Heady C, Woo WT. Fiscal management and economic reform in the People's Republic of China. Oxford: Oxford University Press 1995; 81-135.

[16] Lam T. Institutional constraints, leadership and development strategies. In: Chung JH, Ed. Cities in China: Recipes for economic development in the reform era. London: Routledge 1999; pp. 25695.

[17] Hsu SP. Local tax effort in Shanghai, 1987-93: Decentralization vs local fiscal balance. Iss Stud 2000; 36(6): 116-38.

[18] Zhu, J. Local growth coalition: The context and implications of China's gradualist urban land reforms. Int J Urb Reg Res 1999; 23(3): 534-48.

[19] Zhang T. Urban development and a socialist pro-growth coalition in Shanghai. Urb Aff Rev 2002; 37(4): 475-99.

[20] Jessop B. The political economy of scale. In: Perkmann M, Sum N, Eds. Globalisation, regionalization and cross-border regions. New York: Palgrave Macmillan 2002; pp. 25-49.

[21] Smith N. Scale. In: Johnston RJ, Gregory D, Pratt G, Watts M, Eds The Dictionary of human geography. Oxford: Blackwell Publishers Ltd 2000; pp. 724-7.

[22] Wang Y, Liu X, Lang P, Eds. Administrative system reform in China in past 20 years. Zhengzhou: Zhongzhou Ancient Books Press 1998. 
[23] Mingpao. Reform 1.3 million public units involving 28 million employees and the approval power of government may be decentralized. Mingpao (A Daily Newspaper), 11 November 2002.

[24] The Department of Regional Economy of the State Development Planning Commission of China, Japan International Cooperation Agency. Urbanization: Theme of China's modernization. Changsha: Hunan People's Publishing House 2001.

[25] Shen J. Urban and regional development in post-reform China: The case of Zhujiang Delta. Prog Plan 2002; 57(2): 91-140.

[26] Walder A. Local governments as industrial firms: An organizational analysis of China's transitional economy. Am J Soc 1995; 101(2): 263-301.

[27] Wei H. From duplicated construction to orderly competition. Beijing: People's Press 2001

[28] Smith N. The new urban frontier: Gentrification and the revanchist city. London: Routledge 1996.

[29] People's Republic China. Law of land administration of China. Beijing: Law Press 2001.

[30] Chan D, Ying W, Cang Y. Eliminating local market fragmentation. Beijing: China Plan Press 2002.

[31] Wang Y, Ed. Studies on the development planning of urbanization in the $10^{\text {th }}$ five-year plan. Beijing: China Plan Press 2001.

[32] Mingpao. Accumulated land sale revenue reached RMB600 billion. Mingpao (A Daily Newspaper), 19 November 2002.

[33] Wu F. China's recent urban development in the process of land and housing marketisation and economic globalisation. Habitat Int 2001; 25(3): 273-89.

[34] Wu F. Real estate development and the transformation of urban space in China's transitional economy, with special reference to Shanghai. In: Logan JR, Ed. The New Chinese city: Globalization and market reform. London: Blackwell 2002; pp. 153-66.

[35] Mingpao. Real estate developers suffer with high vacant rate. Mingpao (A Daily Newspaper), 30 November 2002.

[36] Editorial Committee. Institutional reform of local government in China. Beijing: Xinhua Press 1995.

[37] Dai J. City system of China. Beijing: China Map Publishing House 2001.

[38] Ren Z. A Study on the local government in China. Xian: Northwest University Press 1999.
[39] Shen J. Re-organizing urban space in post-reform China. In: Meligrana J, Ed. Redrawing local government boundaries: An international study of politics, procedures, and decisions. Vancouver: UBC Press 2004; pp. 189-205.

[40] Department of civil affairs of Guangdong province and map publishing house of Guangdong. Atlas of the administrative divisions of Guangdong province. Guangzhou: Map Publishing House of Guangdong 2000.

[41] Chan R, Zhao XB. The relationship between administrative hierarchy position and city size development in China. GeoJournal 2002; 56(2): 97-112.

[42] Yeung YM, Shen J, Eds. Developing China's west: A critical path to balanced national development. Hong Kong: The Chinese University Press 2004

[43] Statistical Bureau of Guangdong. Guangdong statistical yearbook 2001. Beijing: China Statistics Press 2001

[44] Zhou Y, Hu D. Questionnaire survey on the impact of "municipality governing county system" to the counties' economy. Eco Geog 1992; 12(1): 8-14.

[45] Liu J, Wang Y. Systems and innovation: On the development and reform of the city system in China. Nanjing: South-East University Press 2000.

[46] Shen J, Yeung YM. Free trade zones in China: Review and prospect. Occasional Paper 2002; No. 122: 1-36. Hong Kong: Hong Kong Institute of Asia-Pacific Studies, The Chinese University of Hong Kong 2002.

[47] Brenner N. The limits to scale? Methodological reflections on scalar structuration. Prog Hum Geog 2001; 25(4): 591-614.

[48] Shen J. Inter-city relations between Hong Kong and Shenzhen: Implications for urban planning and governance. Plann Dev 2008; 23(2): 2-14.

[49] Luo X, Shen J. Why city-region planning does not work well in China? The Case of Suzhou-Wuxi-Changzhou. Cities 2008; 25(4): 207-17.

[50] Yeung YM, Shen J. Socialist economies in transition: Urban policy in China and Vietnam, In: Geyer HS, Ed. International handbook of urban policy: Contentious global issues. Cheltenham: Edward Elgar Publishing Ltd 2007; Vol. 1: pp. 59-76.

(C) J. Shen; Licensee Bentham Open.

This is an open access article licensed under the terms of the Creative Commons Attribution Non-Commercial License (http://creativecommons.org/licenses/by$\mathrm{nc} / 3.0 /$ ) which permits unrestricted, non-commercial use, distribution and reproduction in any medium, provided the work is properly cited. 